renewable sources such as wind and solar, but small-scale combinedheat-and-power plants, and electricity generated from the recovery of waste industrial heat (see page 138).

This decentralization, in turn, requires a grid that is not just bigger, but smarter. With so many sources and sinks for power - and with buyers, sellers and even programmed refrigerators constantly trying to optimize their energy usage based on the power's momentto-moment price - the electricity-moving system also has to be an information-moving system. Everything from the smart appliances, to the digital meters that will track electrons entering and exiting the wires, to the software that gives operators an overview of energy flow, have to be able to communicate with each other.

And therein lies one of the big challenges: there are no generally accepted standards for such communication. Utilities need those standards before they can make serious investments in the smart grid, as they would otherwise risk throwing money away on obsolete technology. And the manufacturers of smart-grid components want those standards to be international, as they would rather not make a different version of each product for each country.

In the United States, responsibility for forging a consensus on how the components of the smart grid will talk to each other falls to the National Institute of Standards and Technology (NIST), which

received \$10 million for the task in the stimulus bill. NIST should move quickly. Every day that a coal-powered factory can't work out how to sell its excess heat back to the grid means more fossil-fuel energy is wasted. And in the absence of the improvements in distribution efficiency that the smart grid can provide, impatient advocates of renewables - and impatient politicians eager to provide jobs during a downturn — are likely to go overboard on building

"Utilities need communication standards before they can make serious investments in the smart grid." new transmission lines.

At least some new transmission lines are inevitable - the most productive spots for large-scale wind or solar installations tend to be a long way from the population centres where power is consumed. But it is also true that large-scale transmission can sometimes be traded off against small-scale distribution. Increasing the diversity and number of generators while using digital information to distribute electricity more efficiently may extend the usefulness of current wiring.

Add to that a smaller number of carefully sited new lines, and the result may be a grid to carry the world forward into a greener age. But policy-makers shouldn't forget: bigger is not necessarily smarter.

\section{Delicate balance}

\section{China's autocratic approach to environmental issues may not always reap the desired rewards.}

$\mathrm{n}$ an ironic twist, the decidedly authoritarian government of China has received much praise of late from Western environmentalists, who tend to cast themselves as anti-authoritarian types.

China has indeed made laudable efforts in many fields, ranging from wind energy to vehicle-emission standards and pollution control. It has even outlawed free plastic bags. The United Nations Environment Programme gave it rave reviews for its pollution reduction and green measures at the Beijing Olympics (see http://tinyurl.com/ ckllzm). And now, China is planning to push wetlands conservation and restoration projects with a speed and lavishness that is making Western environmentalists envious (see page 134).

But any tally of China's environmental achievements requires a reality check. In some areas, for example, it is not clear whether China has been as successful as it claims. The government never really answered criticism that its much touted pre-Olympic increase in the number of relatively smog-free 'blue sky days' was achieved not by making the skies less polluted, but by moving the monitors to cleaner areas. Moreover, China tends not to listen to critics, which stops some of its well-intentioned projects from achieving their full potential. China could undoubtedly improve the efficiency and the effectiveness of its environmental projects if it opened itself up to more feedback, especially from scientists. A case in point is the nation's wind-energy initiative, which has been hampered by substandard turbine technology and poorly planned grid connections (see Nature 457, 372-374; 2009).
Similar caution needs to be exercised when evaluating China's wetlands projects. China's government is full of engineering prowess, and it can design projects that are beautiful and often breathtaking in concept. But once it has committed itself, other considerations fade - including some that shouldn't. It is worth remembering that neither the 1.24 million people displaced over the past decade by the Three Gorges Dam, nor the ecologists concerned about the dam's environmental toll, had much of a voice in the decision-making. If the government takes a similarly reckless approach to water diversion for wetlands restoration, the project could once again tarnish any environmental good with social harm.

But even in the West, a similarly delicate balance has to be struck. The United States, for example, has been anything but decisive in its efforts to repair the coast of Louisiana, where the bayous were badly damaged by Hurricane Katrina in 2005. That is because doing so would require the forcible seizure of land from thousands of private owners for the construction of weirs and other water-diversion systems. So one value - the common good, which in this case means saving the coast and protecting the millions of people in New Orleans - is in direct conflict with the values of property rights and individual autonomy.

The challenge for environmentalists is to find creative mechanisms to reconcile those values, while respecting all of them. The cap-andtrade approach now being embraced for controlling carbon emissions is a prime example. It uses the market system to achieve pollution reduction while allowing for flexibility and individual choice. The 'environmental services' idea of trying to put an economic value on the benefits provided by, say, coastal wetlands is an approach that is similar in spirit, if less mature. Such mechanisms hold the promise of minimizing or eliminating the need for authoritarian methods East or West. 